\title{
OPPORTUNITIES FOR STUDENTS' INDEPENDENT PROFESSIONAL ACTIVITIES IN DESIGN STUDY PROCESS
}

\author{
Aina Strode \\ Rezekne Higher Educational Institution, Rezekne, Latvia \\ E-mail: aina.strode@ru.Iv
}

\begin{abstract}
The research problem is determined by involvement and competitiveness of young designers in the labour market that is related to the opportunities of gaining professional experience within independent professional activities during the design studies in higher education. The aim of the research is to determine development of the formation of students'-prospective designers' professionalism in the study process. Literature study, questionnaire and interview included in mixed methods design. Qualitative and quantitative data collected from six $4^{\text {th }}$ year students of Rezekne Higher Education Institution Bachelor program "Interior design". The research results show the opportunities for independent professional activities during the design study process in the context of interaction between personality and professional abilities. Key words: design education, higher education, mixed methods design, professionalism.
\end{abstract}

\section{Introduction}

Perception of the role of design in economy, business and well-being of community has significantly changed over the last decade. Design is defined as one of the most important innovation tools in the economic development and finding solutions for environmental and societal challenges, which is reflected in a series of strategic documents both in the European Union and in other world countries.

The aim of design education is to give students the opportunity to acquire professional competencies necessary to work in changing conditions in design and related industries, integrating in the curriculum, in the process of teaching and learning topicalities of design and related fields, promoting the creative, critical and systemic thinking, research skills, self-motivation and culture of lifelong learning (Irbìte, 2014b).

The research problem is determined by instability that characterizes today's reality, changes the range of problems solved by design methods, as well as designer's tasks and work process, therefore, new requirements for skills and knowledge necessary for work in the design industry have been established. The involvement opportunities and competitiveness of young designers in the labour market is still being associated with quantity and quality of professional experience, which is initially possible to obtain through independent professional activities during the study process.

The information about research on design education carried out in Latvia and in the world was inspected during the article development process. In Latvia the research on design education in historical, structural and qualitative aspect is carried out by A. Irbite (Irbīte, 2013; Irbite, 2014a, 2014b). R. Buchanan (1998) analyzes education and professional practice issues in design, emphasizing the design thinking as an opportunity to expand traditionally acquired basic knowledge and skills during studies.

The aim of the research is to determine the development of the formation of students'prospective designers' professionalism in the study process. 
Aina STRODE. Opportunities for students' independent professional activities in design study process

PROBLEMS

OF EDUCATION

IN THE $21^{\text {st }}$ CENTURY

Volume 67,2015

Comparative Analysis of the Concept of Professionalism, Professional Competence and the Content of Students' Independent Professional Activities

The analysis of theoretical sources (Blank et al., 1998; Druzhilov, 2001, etc.) shows that the concept of professionalism is much wider than professional competence. Being a professional does not mean only to know how to do, but also to be able to apply this knowledge and strive for a certain result. This means that assessing professionalism, the effectiveness of professional activity must be assessed (Druzhilov, 2001). In Acmeology the category of professionalism is defined as a qualitative characteristics of subject's activity that determines the level of contemporary content and usage of means when solving the tasks, as well as productive techniques for their implementation (Kuzmina, 1990; Bodalev, 1998; Derkach, 2001; Anisimov, 2002, etc.). In the acquisition of professionalism it is necessary to have proper skills, will and character, willingness to learn independently and improve proficiency. The concept of professionalism is not limited to the characteristics of skilled labour, it is also a particular worldview of a human (Druzhilov, 2005).

V. Bodrov's (Бодров, 2001) explanation of professionalism in the structure of professionally oriented personality indicates the professionalism as the highest peak, which is based on professional knowledge, professional experience, professional competence and professional effectiveness. This structure confirms the systematic character of professionalism. Professionalism is the result of interaction of two systems - personality and professional activity.

A component of professionalism is professional competence. I. Maslo and I. Tilla (Maslo \& Tilla, 2005) define competence as an individual combination of skills and experience grounded in experience-generating opportunities. "In procedural meaning it continually develops because skills are developed lifelong and experience is gained continually and there are always new opportunities for gaining experience" (Tillı, 2005, p. 39). H. Huber, F. Senger (1942) and V. Bohm (1979) connect the concept of competence with the sphere of professional activity. They deal with the competence as the expression of abilities through professional activities, therefore competence is revealed in professionalism.

The component of activity in the structure of professionalism characterizes the experience gaining process.

Analyzing professionalism and various aspects of specialist's maturity A. Markova (Маркова, 1996) classifies four types of professional competence: special, social, personal and individual. Special competence or professional competence of activities characterizes the implementation of activity at a high level and includes not only proper knowledge, but also the ability to apply knowledge in practice. Social professional competence is characterized by the skills of using approaches of mutual professional activities and cooperation, which are adopted among professionals. Personality professional competence is characterized by the skills of using self-expression and self-development techniques, specialist's skills to plan his work, to make decisions independently, to see the problems. Individual professional competence is characterized by the skill of using self-regulation, professional development, and sustainable professional motivational techniques.

Students' independent professional activities are formed on the basis of general and professional knowledge, skills and attitudes, which in turn form and develop in the result of professional activity and professional cooperation, as well as in self-organized professional activity (Strode, 2010).

\section{Methodology of Research}

The literature study, the questionnaire and the interview included in mixed methods design. Qualitative and quantitative data collected from six $4^{\text {th }}$ study year students of Rezekne 
Higher Education Institution (Latvia) Bachelor program "Interior design". Gender division: 5 - women, 1 - man. Age range: 22-24 years. The research was conducted in October 2015.

Comparative analysis of the concept of professionalism, professional competence and the content of students' independent professional activity has been carried out in order to determine the categories and concepts for the content analysis of group interview.

In the questionnaire students answered which responsibilities and tasks they performed in the study process at university, in practice at company or as the independent professional activity. Responsibilities and tasks $(n=44)$ from Interior designer's professional standard (MK noteikumi Nr.461, 2010) were included in the questionnaire. According to each accomplished professional task students had to mark one or more choices. Students filled in the questionnaire form and sent it to the author by email. The questionnaire analysis was performed by counting frequency of answer options.

The next stage of the research was carried out in a group structured interview. Its aim was to find out the students' opportunities to carry out professional tasks in the study process.

A group interview is the way how to collect qualitative data by involving a small group of people. In a short time the method allows to get a lot of information. There is a minus people with different or unpopular views may withhold their true thoughts.

Each of the six students answered to the questions about their professional activities during their studies and plans after graduation. The group interview was carried out in an auditorium. The interview time - 40 minutes. The respondents' answers were recorded on the tape. The transcription of the group interview was done successively, i.e. each student's answers were marked by student identification letter: A, B, C, D, E, F.

In the analysis of group interview the relational content analysis was used, determining the compliance of content units with the sub-categories and categories.

\section{Results of Research}

\section{Analysis of Questionnaire Results}

Although the questionnaire was completed by respondents who are studying in the same study program and in the same group, the tasks set in the professional standard were performed very differently in each case (in the study process, in practice, or independent professional activity). In all cases, the largest number of positive responses was marked in the column "independently". Evaluating the completed questionnaires as a whole, the most marked tasks are included in the tasks of Interior designer's professional standard specified in sections "1. Specify the requirements", "2. Analyze data and coordinate project components" and "3. Develop a full range of interior design project" (see Table 1). The smallest number of answers is related to the professional obligations "5. Plan project implementation, perform author's supervision" (see Table 2). When viewing all 6 cases, none of professional tasks was marked in all 3 possible options $(\Sigma=18)$. The tables present the insight into the most frequently indicated options $(\Sigma=17)$ (see Table 1) and the least frequently indicated $(\Sigma=5)$ (see Table 2) professional tasks. 
PROBLEMS

OF EDUCATION

IN THE $21^{\text {st }}$ CENTURY

Volume 67,2015

Table 1. The most frequently performed professional tasks.

\begin{tabular}{llll}
\hline Tasks/ Interior designer's professional standard & \multicolumn{1}{l}{$\begin{array}{l}\text { During } \\
\text { (the numbering corresponds to Interior designer's responsibilities } \\
\text { indicated in the professional standard (MK noteikumi Nr.461, 2010) }\end{array}$} & $\begin{array}{l}\text { In practice } \\
\text { studies }\end{array}$ & $\begin{array}{l}\text { Indepen- } \\
\text { dently }\end{array}$ \\
\cline { 2 - 4 } & 6 -number of cases & 6 \\
\hline 2.1. Analyze the information related to the project & 6 & 5 & 6 \\
\hline $\begin{array}{l}\text { 2.3. Analyze structural, functional, stylistic and contextual characteristics of } \\
\text { the projected object }\end{array}$ & 6 & 6 & 6 \\
\hline $\begin{array}{l}\text { 2.9. Calculate the costs of the project } \\
\text { 3.6. Choose finishing materials, finishing forms and interior coloristic solu- } \\
\text { tions appropriate to functions and style of the room }\end{array}$ & 6 & 4 & 6 \\
\hline $\begin{array}{l}\text { 3.8. Choose and assemble furniture and light fixtures appropriate to design } \\
\text { concept }\end{array}$ & 6 & 4 & 6 \\
\hline
\end{tabular}

Table 2. The least frequently performed professional tasks.

\begin{tabular}{|c|c|c|c|}
\hline $\begin{array}{l}\text { Tasks/ Interior designer's professional standard (MK noteikumi Nr.461, } \\
\text { 2010) }\end{array}$ & $\begin{array}{l}\text { During } \\
\text { studies }\end{array}$ & In practice & $\begin{array}{l}\text { Indepen- } \\
\text { dently }\end{array}$ \\
\hline 4.3. Conform the project documentation; & 3 & 0 & 2 \\
\hline 5.4. If necessary, draw up the project implementation cost estimates; & 2 & 0 & 3 \\
\hline $\begin{array}{l}\text { 5.5. Monitor the congruence of implementation with the concept of the project } \\
\text { and aesthetic and technical qualities; }\end{array}$ & 0 & 2 & 3 \\
\hline $\begin{array}{l}\text { 5.9. Find optimal problem-solving ways and conform them to other specialists } \\
\text { and customers. }\end{array}$ & 0 & 3 & 2 \\
\hline $\begin{array}{l}\text { 6.2. Observe the rules and regulations of safe usage of electrical appliances } \\
\text { appropriate to the workplace and equipment; }\end{array}$ & 0 & 2 & 3 \\
\hline $\begin{array}{l}\text { 6.3. Observe employees' health safety regime appropriate to the workplace and } \\
\text { work equipment; }\end{array}$ & 2 & 2 & 1 \\
\hline
\end{tabular}

\section{Analysis on Group Interview}

At the beginning of the interview students were asked about the work that they would like to do after graduation. Many students (A, B, C, F) expressed the wish to build their own business. Some (A, F) students feel that they would not want to spend all day working at the computer. Facing with professional work environment, many (A, B, C, F) respondents have understood that the initial idea of the designer's profession as a creative occupation has changed since the designer's task is to fulfil the wishes of the client, which is not always in line with the designer's point of view. Student D has recently begun to work in the design office and is convinced that after acquiring university diploma, she will continue doing the same work connected with the preparation of project materials, drawings and visualization design. This student, unlike the others, during her studies had been independently doing contractual work of interior designer. She admits that the work is impossible without graphical programs and without computer skills and these skills are also appropriately rewarded. As an argument for her independent activities the student mentions her interest in the chosen profession and the desire to act, gaining experience. Other students (A, B, C, E, F) admit that they have gained professional experience by meeting the orders of their friends and acquaintances, sometimes in the interior, but mainly in the field of graphic design, because they have acquired appropriate knowledge and skills in the study process. 
According to students' opinion, the selection of the practice place is related to the individual interests in exploring a specific field of design. For example, student $\mathrm{C}$ chose to work in the Museum of Applied Art and Design with the aim to learn about the side-scenes of the organization of exhibitions in the museum and he was surprised about the diversity of work to be done, which is not always related to interior designer's competencies. Assessing labour market demand, a number of students (A, B, E) have chosen to improve their knowledge and skills while working in companies and dealing with the development of graphic design. Student $\mathrm{F}$ believes that it is important to have practice in the manufacturing facilities where it is possible to see the process.

The students consider that the ability to concentrate on task performance, the opportunity to work beyond working hours (A, B, E) and the ability to communicate (D, F) are significant for professional work. Student $\mathrm{C}$ mentions his inability to perform the work within the specified time as an obstacle. It has always caused problems in the study process, so he is not involved in independent professional tasks yet.

Everyone feels that the work with a client, based on communication skills, as well as the need to create ever-new, original design are the most difficult things in designer's work. Student D has positively assessed knowledge and skills acquired in the study process, which provides extensive opportunities for the selection of activities. All students expressed a common idea that performing a particular task, the gaps in knowledge and skills should be mastered independently.

\section{Table 3. Content units, sub-categories and categories identified in the group interview.}

\begin{tabular}{|c|c|c|}
\hline Content units & Sub-category & Category \\
\hline $\begin{array}{l}\text { Computer skills pay off (D) } \\
\text { RELUX program acquired in practice is useful (E) } \\
\text { I have consulted and created posters, etc. (A) } \\
\text { I have created and printed labels }(C) \\
\text { I have been very required for creating a visualization (D) } \\
\text { I've run the project implementation process - recruited workers, } \\
\text { visited shops together ... (D) }\end{array}$ & $\begin{array}{l}\text { Special (activity) professional } \\
\text { competence } \\
\text { (Special knowledge, skills } \\
\text { to apply the obtained knowl- } \\
\text { edge practically) }\end{array}$ & $\begin{array}{l}\text { Professional knowl- } \\
\text { edge and abilities }\end{array}$ \\
\hline $\begin{array}{l}\text { There should be created a team, in individual enterprises too } \\
\text { (F) } \\
\text { It is difficult to offer personal and individual, put your own char- } \\
\text { acter and nothing can be done (F, E) } \\
\text { Working individually you may refuse to work with the client, but } \\
\text { at the office you have to do your work (D) } \\
\text { It is necessary to be able to understand people, to convince } \\
\text { them not by speaking, but by displaying a number of high- } \\
\text { quality samples (B) }\end{array}$ & $\begin{array}{l}\text { Social professional compe- } \\
\text { tence } \\
\text { (Skills of using mutual } \\
\text { professional activities and } \\
\text { cooperation techniques that } \\
\text { are accepted among) profes- } \\
\text { sionals }\end{array}$ & \multirow{2}{*}{$\begin{array}{l}\text { General personal } \\
\text { abilities }\end{array}$} \\
\hline $\begin{array}{l}\text { I don't feel that I do not want to do it - sometimes I do it faster, } \\
\text { but sometimes slower (D) } \\
\text { When I start doing the task, it fascinates }(E) \\
\text { If in the beginning I am lazy, then at the end I have to hurry up } \\
\text { and accomplish the task(C) } \\
\text { Salary disciplines the process of work (F) } \\
\text { Personally, I have high requirements for quality, which are not } \\
\text { always possible to implement (F) } \\
\text { A person always has to learn (A) }\end{array}$ & $\begin{array}{l}\text { Personality and individual } \\
\text { professional competence } \\
\text { (Specialist's skills to plan his } \\
\text { professional activity, to make } \\
\text { decisions independently } \\
\text { and to see the problems. } \\
\text { Skills of using techniques of } \\
\text { self-regulation, professional } \\
\text { development, sustainable } \\
\text { professional motivation). }\end{array}$ & \\
\hline
\end{tabular}


Aina STRODE. Opportunities for students' independent professional activities in design study process

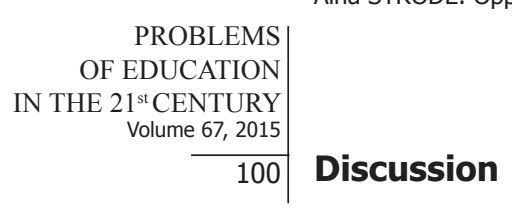

Mixed methods design of the research allows to generalize the role of design education in specialists' training and to determine the factors influencing the success of development of their professionalism. The questionnaire on the performance of professional tasks and group interview proved V. Bodrov's (Бодров, 2001) explanation of professionalism as the result of interaction of two systems - personality and professional activity. According to A. Markova (Маркова, 1996) the characteristics of special, social, personal and individual competencies indicates professional targets of prospective designers, and their implementation is proved by the results obtained in the study process and independent work.

Students of one study program pointed to different professional activity tasks that have been acquired during the study process, practice and independent professional activities. This reflects both the interest in the chosen profession and the willingness (or otherwise - unwillingness) to gain professional experience, which is important in order to show the obtained knowledge and skills in the profession to the employer. Moreover, the skills of applying techniques of self-regulation, personal growth and sustainable professional motivation are significant in the study process and professional activity. The development of design projects is usually connected with certain deadlines, which raises the professional's ability to plan his professional activities, to make independent decisions, to see the problems. Similarly evaluating the design education in universities, J. Frascara (2007) points to the need to acquire professional knowledge and skills, as well as successful communication strategies that are an important part of the professional activity, and to introduce them purposefully into study courses and study projects. American researcher R. V. Zande (2011) illustrates the ways in which design education fosters the skills needed in the global $21^{\text {st }}$ century to help students make a better life for themselves and their community and improve the world. These are: innovation and creativity, flexibility and adaptability, collaboration or working as a team member, problem solving and critical thinking, and communication.

Students, who are ready to pursue independent professional activities are in demand both in the practice areas, and receive offers of employment, regardless of the actual situation in the structure of labour market, because in Latvia there are no industrial enterprises, which can offer a permanent job for designers. The country cannot be considered as the employer for the professionals of the field of design. Focus group interview confirms that, in spite of the acquisition of the study program "Interior design", students see their activities as possible in the field of graphic design. This shows the benefit of the content of the program, which creates the basis for the acquisition of professional knowledge and their diverse use in the field of design, according to labour market demand.

Interview results are consistent with A.Irbite's (2014b) studies on the structure of labour market in the sphere of design. She concludes that the most available vacancies in 2014 were in the field of advertising and printing and publishing industry. The interior designers are offered vacancies in architectural and design companies. However, the number of school and university graduates of design programs and their distinctive competencies are the factors that influence the fact that not all of them can work in the sphere of design and architecture or set up their own businesses. This is confirmed by the survey, where comparing different cases there is very different students' self-esteem on performance of professional tasks. Students, who have carried out professional tasks independently, confirmed in the discussion their purposefulness in the choice of career and appropriate qualities of personality. 


\section{Conclusions}

The results of questionnaire confirm the possibilities of tasks to be carried out in the study process in the context of professionalism, characterized by study projects and course assignments, basing on the lecturer's requirements. If the student does not strive to take responsibility for the project implementation during practice or independent professional activity, then a part of tasks related to practical work remains unsatisfied and possibly causes problems for the choice of profession and the student is not able to show his professional competence to employer and feels insecurity in taking up the duties.

Group interview results allow concluding that independent professional activities require both special professional knowledge and skills and personal qualities and abilities that are important components of professionalism. In order to implement independent activity, an individual must have certain individual character traits and skills that can be developed by persistent work. These are skills to make decisions and take responsibility for them; to think analytically and to see the development of events in perspective; ability and desire to learn, to acquire new knowledge; creativity; reliance on own merits; purposefulness; the ability to interact; the ability to learn from personal mistakes, etc.

In order to ensure students' independent professional activities in the design study process, the author recommends to abide the conditions of individual values, as well as the content, activities and structure of the study process that include the result of interaction between personality and professional activities and lead to professionalism. It appears in:

- student-oriented and socially oriented study work;

- providing availability of students' independent professional activities;

- ensuring unity of theory and practice.

\section{References}

Blank, L. L., Race, K. E., \& Cipparrone, N. (1998). Can professionalism be measured? Academic Medicine, 73, 1119-1121.

Bohm, W. (1979). Methods of studying root systems. Berlin: NY: Springer-Verlag.

Buchanan, R. (1998). Education and professional practice in design [Electronic version]. Design Issues, 14(2), 63-66.

Frascara, J. (2007). Hiding lack of knowledge: bad words in design education [Electronic version]. Design Issues, 23(4), 62-68.

Huber, H., \& Senger, F. (1942). Das Studium ohne Reifezeugnis an den deutschen Hochshulen: amtiliche Bestimmungen. Berlin: Weidmannsche Verlagsbuchhandlung.

Irbite, A. (2014a). Complex problems in design and design education. The 2nd Global Virtual Conference, Volume: 2, Issue: 1 (pp. 287-292). Retrieved September 29, 2015, from file://C:/Users/user/ Downloads/Complex\%20problems\%20in\%20desig.pdf.

Irbite, A. (2014b). The importance of the paradigm shift in the development of design industry and design education. In S. Usca (Ed.), Proceedings of the International Scientifical Conference „, Society, Integration, Education": Vol. 2 (pp. 411-422). Rezekne: RA Publishing house.

Irbīte, A. (2013). Dizaina izglītība Latvijā [Design education in Latvia]. A. Kangro (red.), LU raksti, 792. sēj: Izglītības vadība (57.-62. lpp.). Rīga: LU Akadēmiskais apgāds.

Maslo, I., \& Tilııa, I. (2005). Kompetence kā audzināšanas ideāls un analītiskā kategorija [Competence as a ideal of upbringing and analytical category]. Skolotājs, 3, 4-9.

MK noteikumi Nr.461 [Cabinet Regulations No.461]. (2010). Retrieved September 15, 2015 from http:// likumi.lv/doc.php?id=210806.

Strode, A. (2010). Students' independent professional activity in pedagogical practice. Journal of Teacher Education for Sustainability, 12(2), 38-58.

Tiḷıla, I. (2005). Sociālkultūras mācī̌sanās organizācijas sistēma [Socio-cultural learning organization system]. Riga: RaKa. 
Aina STRODE. Opportunities for students' independent professional activities in design study process

PROBLEMS

OF EDUCATION

IN THE $21^{\text {st }}$ CENTURY
Volume 67, 2015

102

Zande, R. V. (2011). Design education supports social responsibility and the economy [Electronic version]. Arts Education Policy Review, 112, 26-34. DOI: 10.1080/10632913.2011.518123

Анисимов, О. С. (2002). Педагогическая акмеология: общая и управленческая [Educational acmeology: general and administrative]. Минск: Технопринт УП.

Бодалев, А. А. (1998). Вершина в развитии взрослого человека. Характеристики и условия достижения [Peak in the development of adult human. Specifications and conditions of achievement]. Москва: Флинта.

Деркач, А. А. (2001). Развитие иенностной сферы профессионала [The development of valuable sphere of a professional]. Москва: Изд-во РАГС.

Дружилов, С. А. (2001). Обучение и стадии профессиональной компетентности [Education and stages of professional competence]. Непрерывное образование как условие развития творческой личности (32-33 стр.). Новокузнецк: ИПК.

Кузьмина, Н. В. (1990). Профессионализм личности преподавателя и мастера производственного обучения [The professionalism of the personality of teacher and trainer]. Москва: Высшая школа.

Advised by Velta Lubkina, Rezekne Higher Educational Institution, Latvia

Received: October 10, 2015

Accepted: October 22, 2015

Aina Strode

Dr.paed., Assistant Professor, Faculty of Education, Language and Design, a Leading Researcher, Research Institute for Regional Studies, Rezekne Higher Educational Institution (Rezeknes Augstskola), Atbrīvošanas al. 115, , LV-4601 Rezekne, Latvia.

E-mail: aina.strode@ru.lv

Website: http://www.ru.Iv/regi_personals 